\title{
A Microbiological, Toxicological, and Biochemical Study of the Effects of Fucoxanthin, a Marine Carotenoid, on Mycobacterium tuberculosis and the Enzymes Implicated in Its Cell Wall: A Link Between Mycobacterial Infection and Autoimmune Diseases
}

\author{
Miroslava Šudomová ${ }^{1}$, Mohammad Ali Shariati ${ }^{2}$, Javier Echeverría ${ }^{3}{ }^{\oplus}$, \\ Ioana Berindan-Neagoe ${ }^{4,5,6} \mathbb{D}$, Seyed Mohammad Nabavi ${ }^{7, *}$ and Sherif T. S. Hassan ${ }^{8, *(\mathbb{D})}$ \\ 1 Museum of Literature in Moravia, Klášter 1, 66461 Rajhrad, Czech Republic; sudomova@post.cz \\ 2 Kazakh Research Institute of Processing and Food Industry (Semey Branch), Semey 071410, Kazakhstan; \\ shariatymohammadali@gmail.com \\ 3 Departamento de Ciencias del Ambiente, Facultad de Química y Biología, Universidad de Santiago de Chile, \\ Casilla 40, Correo 33, Santiago 9170022, Chile; javier.echeverriam@usach.cl \\ 4 Research Center for Functional Genomics, Biomedicine and Translational Medicine, University of Medicine \\ and Pharmacy "Iuliu-Hatieganu", 400337 Cluj-Napoca, Romania; ioananeagoe29@gmail.com \\ 5 MedFuture Research Center for Advanced Medicine, University of Medicine and Pharmacy \\ "Iuliu-Hatieganu”, 400349 Cluj-Napoca, Romania \\ 6 Department of Functional Genomics and Experimental Pathology, The Oncology Institute "Prof. Dr. Ion \\ Chiricuţă", 400015 Cluj-Napoca, Romania \\ 7 Applied Biotechnology Research Center, Baqiyatallah University of Medical Sciences, \\ Tehran 14359-16471, Iran \\ 8 Department of Natural Drugs, Faculty of Pharmacy, University of Veterinary and Pharmaceutical Sciences \\ Brno, Palackého tř. 1946/1, 61242 Brno, Czech Republic \\ * Correspondence: nabavi208@gmail.com (S.M.N.); sherif.hassan@seznam.cz (S.T.S.H.); \\ Tel.: +420-774-630-604 (S.T.S.H.)
}

Received: 23 September 2019; Accepted: 11 November 2019; Published: 14 November 2019 updates

\begin{abstract}
This study explored the antitubercular properties of fucoxanthin, a marine carotenoid, against clinical isolates of Mycobacterium tuberculosis (Mtb). Two vital enzymes involved in $\mathrm{Mtb}$ cell wall biosynthesis, UDP-galactopyranose mutase (UGM) and arylamine- $N$-acetyltransferase (TBNAT), were selected as drug targets to reveal the mechanism underlying the antitubercular effect of fucoxanthin. The obtained results showed that fucoxanthin showed a clear bacteriostatic action against the all Mtb strains tested, with minimum inhibitory concentrations (MIC) ranging from 2.8 to $4.1 \mu \mathrm{M}$, along with a good degree of selectivity index (ranging from 6.1 to 8.9 ) based on cellular toxicity evaluation compared with standard drug isoniazid (INH). The potent inhibitory actions of fucoxanthin and standard uridine- 5 '-diphosphate against UGM were recorded to be $98.2 \%$ and $99.2 \%$, respectively. TBNAT was potently inactivated by fucoxanthin (half maximal inhibitory concentration $\left(\mathrm{IC}_{50}\right)=4.8 \mu \mathrm{M} ; 99.1 \%$ inhibition $)$ as compared to $\mathrm{INH}\left(\mathrm{IC}_{50}=5.9 \mu \mathrm{M} ; 97.4 \%\right.$ inhibition $)$. Further, molecular docking approaches were achieved to endorse and rationalize the biological findings along with envisaging structure-activity relationships. Since the clinical evidence of the last decade has confirmed the correlation between bacterial infections and autoimmune diseases, in this study we have discussed the linkage between infection with $\mathrm{Mtb}$ and autoimmune diseases based on previous clinical observations and animal studies. In conclusion, we propose that fucoxanthin could demonstrate great therapeutic value for the treatment of tuberculosis by acting on multiple targets through a bacteriostatic effect as well as by inhibiting UGM and TBNAT. Such outcomes may lead to avoiding or decreasing the susceptibility to autoimmune diseases associated with Mtb infection in a genetically susceptible host.
\end{abstract}


Keywords: Mycobacterium tuberculosis; autoimmunity; fucoxanthin; marine carotenoid; UDP-galactopyranose mutase; arylamine- $N$-acetyltransferase; pathogenesis

\section{Introduction}

Mycobacterium tuberculosis (Mtb) is a pathogenic microorganism that targets alveolar macrophages and induces tuberculosis in humans and animals [1]. Tuberculosis is one of the main global health challenges of all time. Although the current antitubercular drugs applied in the clinic have lessened mortality, Mtb resistance to these medications has become a global challenge facing public health $[2,3]$. Galactofuranose (Galf) is a critical part of the arabinogalactan that connects the peptidoglycan layer and the mycolic acid layer in the cell wall of Mtb [4]. UDP-galactopyranose mutase (UGM) is a key enzyme involved in Galf metabolism and catalyzes the interconversion of UDP-galactopyranose (UDP-Gal $p$ ) to UDP-galactofuranose (UDP-Galf) [5]. Removal of the gene encoding for UGM in Mtb revealed that this enzyme is necessary for mycobacterial cell wall biosynthesis. Since Galf and UGM are not detected in humans, UGM has been reported to be a vital target for therapeutic intervention $[6,7]$. Arylamine- $N$-acetyltransferase (NAT) is a cytosolic enzyme that catalyzes the transfer of the acetyl group from acetyl coenzyme A (AcCoA) to the free amino group of arylamines and hydrazines [8]. Mtb contains and expresses the gene encoding the NAT protein, and hence deleting the gene for arylamine- $N$-acetyltransferase from Mtb (TBNAT) leads to a decrease of mycobacterial cell wall lipid biosynthesis $[9,10]$. Therefore, TBNAT has been observed to be a crucial drug target for tuberculosis treatment [10]. The development of new antitubercular agents is imperative and is required to provide additional therapeutic alternatives. Over the past few decades, natural products, especially marine-derived metabolites, have gained considerable attention in drug discovery [11].

Fucoxanthin is a naturally occurring carotenoid and is extensively scattered in edible brown seaweeds and diatoms $[12,13]$. This molecule belongs to the group of xanthophylls and non-provitamin A carotenoids and contains unusual functional groups, including a unique allenic bond, nine unconjugated double bonds, a 5,6-monoepoxide moiety, and other oxygenic functional moieties [14,15]. While fucoxanthin remains a poorly studied marine metabolite, this substance has been reported to provide various health benefits, including antioxidant effects, anticancer properties, anti-obesity and anti-diabetic activities, anti-acetylcholinesterase properties, and good effects on the cardiovascular system through reducing cholesterol and triacylglycerol levels as well as lowering blood pressure and inflammatory processes [16-21]. In this report, we aimed to explore, for the first time, the antitubercular properties of fucoxanthin against clinical isolates of $\mathrm{Mtb}$ along with the inhibition activities against UGM and TBNAT. Besides, the cellular toxicity of fucoxanthin has been evaluated. The correlation between mycobacterial infection and autoimmune diseases has been also debated.

\section{Results and Discussion}

\subsection{Antimycobacterial and Cytotoxicity Characteristics}

The antimicrobial activity of fucoxanthin and the standard drug isoniazid (INH) was assessed by microdilution assay against ten clinical isolates of $\mathrm{Mtb}$ along with a reference strain. As shown in Table 1, fucoxanthin exhibited a pronounced bacteriostatic effect on the all Mtb strains tested (expressed as minimum inhibitory concentration (MIC) values ranging from 2.8 to $4.1 \mu \mathrm{M}$ ) as compared to INH (MIC values ranging from 4.8 to $6.2 \mu \mathrm{M}$ ). 
Table 1. Bacteriostatic effect of fucoxanthin and isoniazid on Mycobacterium tuberculosis strains and cytotoxicity evaluation.

\begin{tabular}{|c|c|c|c|c|c|}
\hline \multirow{2}{*}{$\begin{array}{l}\text { Mycobacterial } \\
\text { Strains }\end{array}$} & \multicolumn{2}{|c|}{$\operatorname{MIC}(\mu \mathrm{M})$} & \multirow{2}{*}{$\begin{array}{l}\text { Cytotoxicity }\left(\mathrm{IC}_{50} ; \mu \mathrm{M}\right) \text { for } \\
\text { Fucoxanthin and INH }\end{array}$} & \multicolumn{2}{|l|}{ SI } \\
\hline & Fucoxanthin & INH & & Fucoxanthin & INH \\
\hline $\mathrm{Mtb}^{\mathrm{a}}$ & 4.1 & 6.2 & $>25$ & $>6.1$ & $>4.0$ \\
\hline Mtb-A $b$ & 3.9 & 5.8 & $>25$ & $>6.4$ & $>4.3$ \\
\hline Mtb-B ${ }^{b}$ & 3.9 & 5.2 & $>25$ & $>6.4$ & $>4.8$ \\
\hline$M+b-C^{b}$ & 3.8 & 5.3 & $>25$ & $>6.6$ & $>4.7$ \\
\hline Mtb-D ${ }^{b}$ & 3.5 & 5.5 & $>25$ & $>7.1$ & $>4.5$ \\
\hline Mtb-E ${ }^{b}$ & 3.6 & 5.5 & $>25$ & $>6.9$ & $>4.5$ \\
\hline Mtb-F b & 2.9 & 4.8 & $>25$ & $>8.6$ & $>5.2$ \\
\hline Mtb-G ${ }^{b}$ & 2.9 & 4.9 & $>25$ & $>8.6$ & $>5.1$ \\
\hline $\mathrm{Mtb}-\mathrm{H}^{\mathrm{b}}$ & 3.0 & 5.1 & $>25$ & $>8.3$ & $>4.9$ \\
\hline Mtb-I ${ }^{b}$ & 2.8 & 4.8 & $>25$ & $>8.9$ & $>5.2$ \\
\hline Mtb-J b & 3.1 & 5.2 & $>25$ & $>8.1$ & $>4.8$ \\
\hline
\end{tabular}

The displayed values demonstrate the average of three independent measurements conducted in triplicate. ${ }^{\mathrm{a}}$ Mtb: Mycobacterium tuberculosis (standard strain; $\mathrm{H}_{37} \mathrm{Rv}$ CNCTC My 331-88/ATCC 27294); ${ }^{b}$ Mtb: Clinical isolates of Mycobacterium tuberculosis; MIC: minimum inhibitory concentration; INH: isoniazid; $\mathrm{IC}_{50}$ : half maximal inhibitory concentration (expressed as toxicological value); SI: selectivity index expressed as the ratio $\mathrm{IC}_{50} / \mathrm{MIC}$. The statistical analyses were aided by PRISM software (GraphPad Software, Inc., La Jolla, CA, USA; version 8.0).

Globally, the fast-rising frequency of infection with Mtb resulted in an extensive use of antibiotics, which in turn led to the development of drug resistance. Consequently, treatment failure has been established. Therefore, to defeat such complexities there is an inescapable necessity to find alternative sources that afford lower resistance and reduced adverse effects with the lowest possible cytotoxicity. Notably, the collected MICs for INH are in the line with the defined MIC breakpoints for INH (recorded for susceptible Mtb strains) as previously conveyed by the Clinical and Laboratory Standards Institute (CLSI) [22]. Although few reports have described the antimicrobial potency of fucoxanthin against various pathogenic bacteria except $\mathrm{Mtb}$, we tried to rationalize our results with these studies [23-26]. However, we present a first investigation on the anti-Mtb activity of fucoxanthin.

The fundamental principle of drug discovery and development is to design a drug that reaches its supposed target at a proper concentration and without cytotoxicity. Therefore, it is an essential process to assess the potential cytotoxicity of any drug that could interfere with its biological action $[27,28]$. Fucoxanthin and INH were tested for their possible cytotoxic impact on normal human fetal lung fibroblast cells. The half maximal inhibitory concentration $\left(\mathrm{IC}_{50}\right)$ values for test molecules that are necessary to diminish the viability of test cells to $50 \%$ compared to a control ( $100 \%$ cell viability) are presented in Table 1 . The results advocate that no cellular toxicity was manifested when cells treated with the test inhibitors, even at a high $\mathrm{IC}_{50}$ value of $25 \mu \mathrm{M}$. Thus, the safety index of fucoxanthin was authenticated by assessing the selectivity index (SI), where fucoxanthin had a cytotoxic effect on normal human fetal lung fibroblast cells at a concentration $(>25 \mu \mathrm{M})$ higher than its MIC values. Our results are in line with a previously published study in which fucoxanthin only induced significant cytotoxicity against human epithelial cervical cancer cells with an $\mathrm{IC}_{50}$ value of $55 \mu \mathrm{M}$ [29]. On the other hand, other studies confirmed the cytotoxic properties of fucoxanthin with a varied range of $\mathrm{IC}_{50}$ values [30-33]. The differences in obtained $\mathrm{IC}_{50}$ values could be assigned to the variation in test assays used, as well as different cell lines sources and experimental conditions used.

In autoimmunity research, it is currently recognized that susceptibility to autoimmune diseases is multifactorial and that the interplay between genetic and environmental factors triggers disease development [34]. Various genetic agents relate to susceptibility to autoimmune disease, and multiple environmental factors are responsible for cracking the tolerance to self-antigens in the susceptible host [35]. Infections with bacterial pathogens, which act as environmental activators, could induce or promote autoimmunity, resulting in clinical manifestations of autoimmune diseases in genetically susceptible individuals [36]. However, how infections are involved in disease inception or flare of many autoimmune diseases remains unknown [35]. Several significant review articles have comprehensively documented and clarified the association between infection with Mtb and susceptibility to autoimmune 
diseases based on in vivo and clinical studies [35,37-40]. Over the past few decades, many treatment strategies have been developed to manage tuberculosis infection, which in turn could pave the way to prevent or decrease the susceptibility to autoimmune diseases linked with this infection [37]. Unfortunately, the development of drug resistance has resulted in a failure of Mtb management. Therefore, new strategies based on natural-based medicine should be considered in large-scale research as an alternative means to conventional therapies.

\subsection{Anti-UGM Evaluation}

This enzyme has been outlined to be critical macromolecule for the biosynthesis of the Mtb cell wall and hence considered an important drug target for tuberculosis therapy. Thus, we further examined whether the bacteriostatic effect of fucoxanthin against Mtb could be attributed to the inhibition of UGM. As presented in Table 2, fucoxanthin was tested in a UGM inhibition assay, where it efficiently inactivated the catalytic function of UGM (turnover $1.1 \%$ and inhibition $98.2 \%$ ) compared with the standard inhibitor uridine-5'-diphosphate (UDP) (turnover 0.5\% and inhibition 99.2\%).

Table 2. Anti-enzymatic properties of fucoxanthin and UDP against UGM.

\begin{tabular}{ccc}
\hline Inhibitors & Turnover $^{\mathbf{a}} \mathbf{( \% )}$ & Inhibition $^{\mathbf{b}} \mathbf{( \% )}$ \\
\hline Fucoxanthin & $1.1 \pm 0.2$ & 98.2 \\
UDP & $0.5 \pm 0.4$ & 99.2 \\
No inhibition & $61.3 \pm 0.7$ & $\mathrm{Nd}$
\end{tabular}

PRISM software (GraphPad Software, Inc., La Jolla, CA, USA; version 8.0) was employed for performing statistical analyses. The data are displayed as the mean \pm standard deviation (SD); each measurement was conducted in triplicate. ${ }^{a} \%$ Turnover was ascertained by integration of the peak of the substrate and the peak of the product. b \% Inhibition was assessed from the \% turnover of the decreased reaction (in the presence of inhibitors) compared to the reaction in the absence of inhibition (no inhibition). Nd: not determined; UDP: uridine- $5^{\prime}$-diphosphate; UGM: UDP-galactopyranose mutase.

It has been proven that the growth of Mtb could be suppressed by inactivating UGM activity [41]. Hence, our results validated this observation, where the antimycobacterial efficacy of fucoxanthin was noted to be related to its inhibitory action against UGM. Since we here provide a first study on the anti-UGM activity of fucoxanthin and no prior studies had been conducted to reveal the inhibitory effects of carotenoids or terpenoids against UGM, we attempted to rationalize our results with a research report in which natural flavonoids showed potent inhibition properties against the UGM of Mtb [42].

\subsection{Anti-TBNAT Evaluation}

TBNAT plays a critical role in Mtb cell wall lipid biosynthesis and hence is appraised as a pivotal drug target for tuberculosis treatment. Consequently, we conducted anti-enzymatic assay against TBNAT to unveil the possible mechanism behind the anti-Mtb activity of fucoxanthin. The results demonstrated that fucoxanthin potently inhibited the activity of $\mathrm{TBNAT}\left(\mathrm{IC}_{50}=4.8 \mu \mathrm{M} ; 99.1 \%\right.$ inhibition) compared with INH ( $\mathrm{IC}_{50}=5.9 \mu \mathrm{M} ; 97.4 \%$ inhibition) (Table 3).

Table 3. Anti-enzymatic actions of fucoxanthin and INH against TBNAT.

\begin{tabular}{ccc}
\hline Inhibitors & Inhibition (\%) & IC $_{\mathbf{5 0}}(\boldsymbol{\mu M})$ \\
\hline Fucoxanthin & $99.1 \pm 0.6$ & $4.8 \pm 0.4$ \\
INH & $97.4 \pm 0.4$ & $5.9 \pm 0.2$ \\
\hline
\end{tabular}

Statistical analyses were performed by PRISM software (GraphPad Software, Inc., La Jolla, CA, USA; version 8.0). The results are shown as the mean \pm standard deviation (SD) of three measurements performed in triplicate. IC 50 : half maximal inhibitory concentration; INH, isoniazid; TBNAT: Mycobacterium tuberculosis arylamine- $N$-acetyltransferase. 
In this work, the inhibition activity of fucoxanthin against TBNAT is reported. Several publicized in vitro and in vivo studies were found to concur with our obtained results, where natural products were declared to have significant inhibitory effects on various types of NAT enzymes (microbial and human enzymes) [43-46].

\subsection{In Silico Analyses}

To further gain insights into the binding mode along with the molecular interactions between fucoxanthin and UGM (Mtb $\mathrm{H}_{37} \mathrm{Rv}$; PDB ID: 4RPJ) and TBNAT (Mtb H${ }_{37} \mathrm{Rv}$; PDB ID: 4BGF), molecular docking analyses were accomplished. These studies were also conducted to validate and justify the outcomes of in vitro assays. Both enzymes were selected as valuable drug targets for the treatment of Mtb infection.

\section{Binding Modes and Molecular Interactions Between Fucoxanthin and UGM and TBNAT}

The docking results revealed that fucoxanthin effectively bound to the active site of UGM (Figure 1). The molecular interaction between fucoxanthin and UGM was formed by crucial connections such as hydrogen bonding, carbon-hydrogen bonding, hydrophobic, and van der Waals interactions with the amino acid residues found in UGM active site, along with the functional groups of fucoxanthin that are accountable for the interactions (Figure 2). All detected amino acid residues were previously suggested to be essential for enzyme suppression [47]. The remarked binding mode of fucoxanthin with UGM active site indicates that this molecule competes with substrate for dominating the active site and accordingly we may suggest fucoxanthin as a competitive inhibitor of UGM.

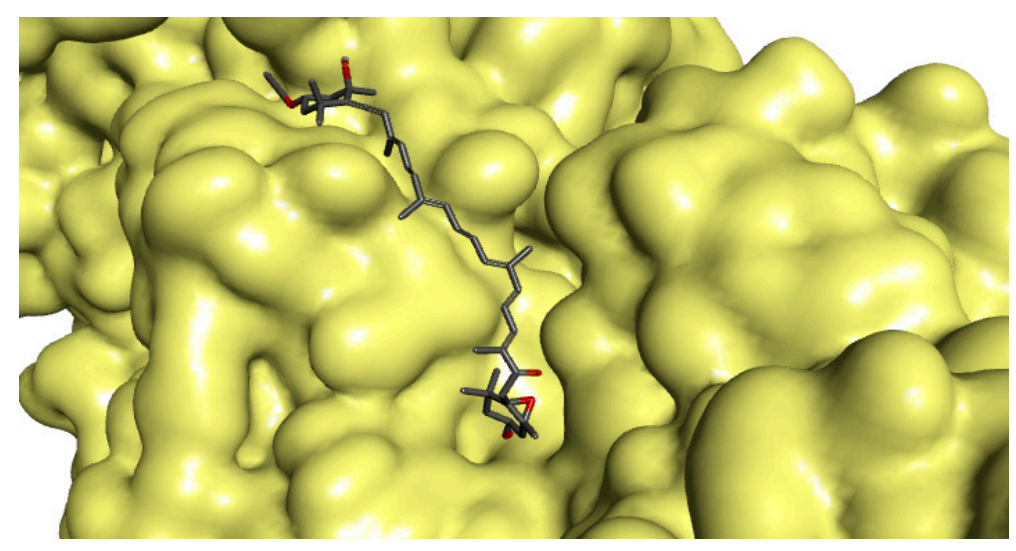

Figure 1. Protein-ligand illustration shows fucoxanthin fastens in the active site of the three-dimensional molecular surface of UDP-galactopyranose mutase (UGM). The docking score for fucoxanthin with the enzyme was found to be $-8.5 \mathrm{kcal} / \mathrm{mol}$ (expressed as a binding affinity value).

The docking outcomes of fucoxanthin-TBNAT complex displayed noticeable binding mode (Figure 3). This binding mode has established significant molecular interactions via forming substantial contacts such as hydrogen bonding, hydrophobic, and van der Waals interactions with amino acid residues of TBNAT active site (Figure 4). Besides, the functional groups of fucoxanthin that perform a vital role in setting up the detected interactions were perceived. All observed amino acid residues of TBNAT active site were previously proposed to be vital for inhibiting TBNAT activity [48,49]. Based on the above-mentioned findings, we may propose fucoxanthin as a competitive inhibitor of TBNAT, where this compound remarkably fitted in the active site and hence struggled with the substrate to reside in the active site. 


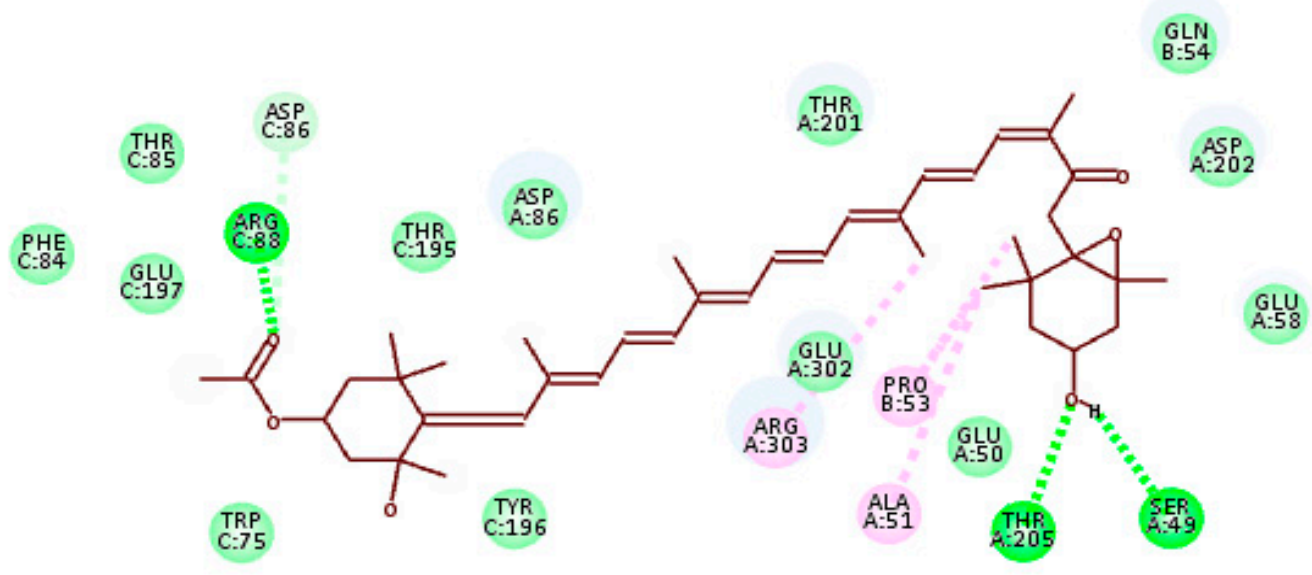

\section{Interactions}

Figure 2. Binding mode and molecular interaction of fucoxanthin with UDP-galactopyranose mutase (UGM). Important interactions with amino acid residues of the active site of the enzyme are depicted. Key functional groups of fucoxanthin that are responsible for creating the molecular interactions with the active site are displayed.

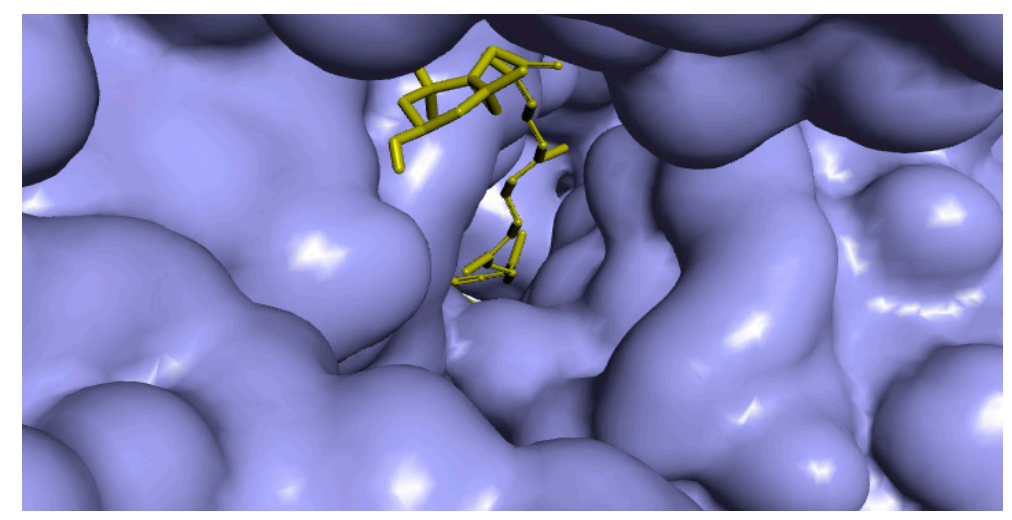

Figure 3. Protein-ligand depiction demonstrates fucoxanthin fastens in the active site of the three-dimensional molecular surface of arylamine- $N$-acetyltransferase from $M$. tuberculosis (TBNAT). The docking score for fucoxanthin with the enzyme was found to be $-7.9 \mathrm{kcal} / \mathrm{mol}$ (presented as a binding affinity value).

Overall, it is important to declare that the results acquired from molecular docking analyses are in accordance with the data of in vitro tests, which, in turn, justify the inhibitory characteristics of fucoxanthin against UGM and TBNAT. 


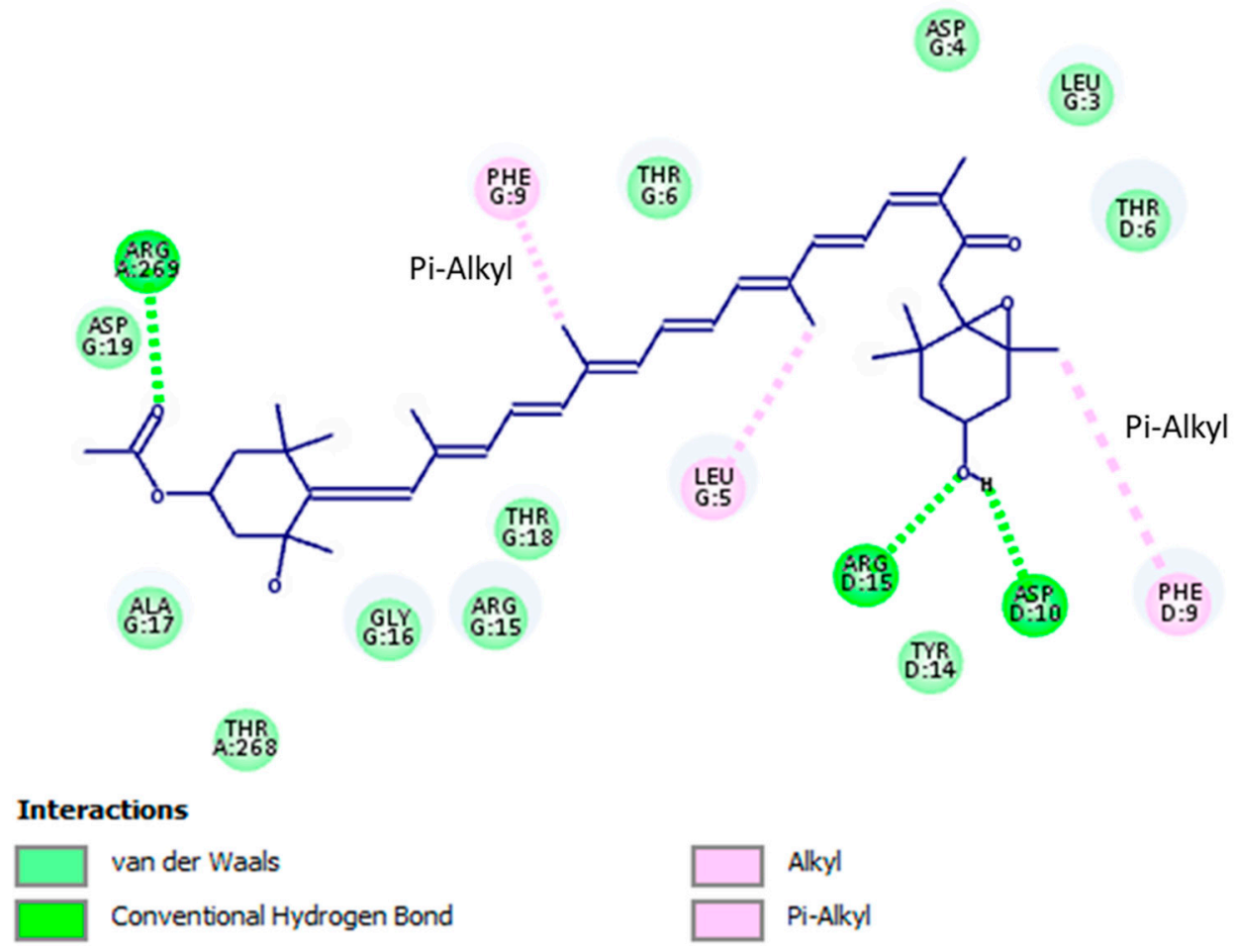

Figure 4. Binding mode and molecular interaction of fucoxanthin with arylamine- $N$-acetyltransferase (TBNAT). Imperative interactions with amino acid residues of the active site of the enzyme are described, where crucial functional groups of fucoxanthin that are accountable for setting up the molecular interactions with the active site are displayed.

\section{Materials and Methods}

\subsection{Antimicrobial Activity}

\subsubsection{Mycobacterial Strains and Culture Conditions}

Ten clinical isolates of Mtb (A, B, C, D, E, F, G, H, I, and J; isolated from patients infected with Mtb) were kindly received from Motol University Hospital (MUH) in Prague, Czech Republic, whereas the reference bacterial strain of $\mathrm{Mtb}\left(\mathrm{H}_{37} \mathrm{Rv}\right.$; CNCTC My 331-88: ATCC 27294) was gained from the Czech National Collection of Type Cultures (CNCTC), National Institute of Public Health, Prague, Czech Republic. The identification of all clinical isolates was ascertained employing biochemical and molecular techniques of the certified guideline of Clinical and Laboratory Standards Institute (CLSI) [50]. Fucoxanthin and isoniazid (INH; a standard antitubercular medication) were purchased from Sigma-Aldrich, Berlin, Germany. All test Mtb strains were observed to be susceptible to INH, and then were cultured and grown following the guideline of the CLSI [22].

\subsubsection{Assessment of Minimum Inhibitory Concentration (MIC)}

Minimum inhibitory concentration of fucoxanthin and INH was assessed by microdilution assay as previously described in CLSI guideline [22]. The negative controls were assigned to be dimethyl sulfoxide (DMSO) and the broth. Here, 1\% DMSO was employed to dissolve and dilute the test compounds and further mixed with broth ( $25 \mu \mathrm{L}$ of DMSO solution in $5 \mathrm{~mL}$ of broth). The used $1 \%$ of DMSO had no effect on the growth of Mtb. Final concentrations of test substances in wells ranged from 2.8 to $6.2 \mu \mathrm{M}$. After $24 \mathrm{~h}$ of incubation, the results were registered and represented as minimal inhibitory concentration (MIC) at a micromolar scale that impeded the blue to pink color change. 


\subsection{Cellular Toxicity Analysis}

\subsubsection{Cell Lines and Culture Requirements}

Normal human fetal lung fibroblast cells (MRC-5; MUH, Prague, Czech Republic) were cultured in Minimum Essential Eagle Medium MEM (Sigma-Aldrich, Berlin, Germany) supplemented with $10 \%$ fetal bovine serum (PAA Laboratories $\mathrm{GmbH}$, Pasching, Autria), $2 \mathrm{mM}_{\mathrm{L}}$-glutamine solution (Sigma-Aldrich, Berlin, Germany), and 1\% non-essential amino acid solution (Sigma-Aldrich, Berlin, Germany), in a humidified state with $5 \% \mathrm{CO}_{2}$ at $37^{\circ} \mathrm{C}$. Subsequently, for subculture the cells were collected after treatment with trypsin/EDTA (Sigma-Aldrich, Berlin, Germany) at $37^{\circ} \mathrm{C}[51]$.

\subsubsection{Cytotoxicity Assessment}

The potential cytotoxicity of fucoxanthin and INH was assessed using a CellTiter-96 assay. This assay is based on the reduction of tetrazolium dye MTS in living cells to formazan, which is then ascertained colorimetrically following the hitherto reported procedure [51]. The MRC-5 cells treated with the test compounds were applied as investigational groups, whereas untreated MRC- 5 cells acted as control groups. The absorbance of test samples was detected at $490 \mathrm{~nm}$ and the inhibitory curves were assembled for each compound, using incubation concentrations vs. percentage of absorbance relative to untreated control. The half maximal inhibitory concentration $\left(\mathrm{IC}_{50}\right)$ was ascertained by a nonlinear regression analysis of the inhibitory curves. The statistical analyses were aided by PRISM software (GraphPad Software, Inc., La Jolla, CA, USA; version 8.0).

\subsection{UGM Assay}

\subsubsection{UGM Expression and Purification System}

The standard strain Mtb $\left(\mathrm{H}_{37} \mathrm{Rv}\right.$ CNCTC My 331-88; ATCC 27,294 obtained from the Czech National Collection of Type Cultures, National Institute of Public Health, Prague, Czech Republic) was used as a source for the expression and purification of the enzyme. The expression and purification system along with the required experimental conditions were followed as previously detailed [52]. The quantitation of the obtained enzyme was assessed as earlier described in detail [53].

\subsubsection{UGM Activity}

UGM activity was accomplished as previously specified [54,55]. Fucoxanthin and the standard UGM inhibitor uridine-5'-diphosphate (UDP; Sigma Chemical Co., St Louis, MO, USA) were prepared in DMSO (DMSO 2\% (v/v) was used in all performed reactions). Concisely, UGM $(25 \mu \mathrm{g} / \mathrm{mL})$ prepared in a buffer (100 $\mathrm{mM}$ of 3-(N-morpholino) propanesulfonic acid (MOPS); $\mathrm{pH}=8.0$ ) was pre-incubated with $\mathrm{Na}_{2} \mathrm{~S}_{2} \mathrm{O}_{3}(20 \mathrm{mM})$ on ice for $1 \mathrm{~min}$. Further, the solution mixture was incubated with the test inhibitors $(20 \mathrm{mM})$ followed by adding the substrate UDP-Galf $(60 \mu \mathrm{M} ; \mathrm{MUH}$, Prague, Czech Republic) at $25{ }^{\circ} \mathrm{C}$. Subsequently, the reactions were stopped at various times by adding ice-cold $\mathrm{HCl}$ and directly subjected to quick freezing in liquid nitrogen. The activity of UGM in the presence of $2 \%(\mathrm{v} / \mathrm{v})$ DMSO was considered a control. A high performance liquid chromatography (HPLC) system (Agilent 1100 series) was applied to monitor UGM activity, where all instrumental setup and operational requirements were tracked according to the detailed procedures [54,55]. The degree of conversion was measured throughout the comparison of the integration of substrate and product peaks.

\subsection{TBNAT Assay}

\subsubsection{TBNAT Expression and Purification System}

A comprehensive system for protein expression and purification was applied to produce TBNAT in a form of recombinant protein utilizing a detailed protocol described by Abuhammad et al. [56]. 
After expression and purification of TBNAT, the enzyme was stocked for additional use at $-80{ }^{\circ} \mathrm{C}$ in Tris- $\mathrm{HCl}(20 \mathrm{mM} ; \mathrm{pH}=8)$ blended with dithiothreitol $(1 \mathrm{mM})$ and glycerol $(5 \%)$.

\subsubsection{TBNAT Activity}

Microplate photometer-based assay was subjected to determine TBNAT-catalyzed reaction with slight refinement [57]. TBNAT activity was detected by monitoring the rate of hydrolysis of acetyl coenzyme A (AcCoA) through detection with 5,5'-dithio-bis(2-nitrobenzoic acid) (DTNB), and the absorbance was recorded at $405 \mathrm{~nm}$ (Tecan Sunrise Plate Reader, Männedorf, Switzerland). To sum up, the test molecules (fucoxanthin and standard INH) were prepared and dissolved in DMSO and all reactions were processed in the presence of DMSO $(2 \% ; \mathrm{v} / \mathrm{v})$. TBNAT (170 ng; prepared in $20 \mathrm{mM}$ Tris- $\mathrm{HCl}(\mathrm{pH}=8)$ mixed with dithiothreitol $(1 \mathrm{mM})$ and 5\% glycerol) was incubated with test compounds ( $5 \mu \mathrm{L}$ at final concentrations ranging from 10 to $20 \mu \mathrm{M}$ ) for $15 \mathrm{~min}$ at $25^{\circ} \mathrm{C}$. Further, $15 \mu \mathrm{L}$ of a substrate hydralazine (30 $\mu \mathrm{M}$; Sigma-Aldrich, Berlin, Germany) and $12 \mu \mathrm{L}$ of acetyl CoA (30 $\mu \mathrm{M})$ were blended with the obtained mixture solution. Subsequently, the reaction was stopped by utilizing $25 \mu \mathrm{L}$ of DTNB (processed in guanidine- $\mathrm{HCl}(6.4 \mathrm{M})$ and Tris- $\mathrm{HCl}(100 \mathrm{mM})$ with $\mathrm{pH}=7.3)$ after $10 \mathrm{~min}$ at $25{ }^{\circ} \mathrm{C}$ and the enzyme activity was achieved as an end-point readout analysis. The TBNAT-catalyzed reaction (no inhibition) was assigned as a control. The \% inhibition was ascertained as the ratio of enzyme activity (expressed as the rate of CoA formation with test molecules) to the activity of the control without inhibition. The inhibitory curves which were obtained by non-linear fitting of the $\%$ inhibition and the logarithmic concentration of the inhibitor versus the response were used to assess $\mathrm{IC}_{50}$ values.

\subsection{In Silico Investigation}

The PyRx docking tool fixed with Autodock VINA software (version 0.8, The Scripps Research Institute, La Jolla, CA, USA) was utilized for conducting the molecular docking analyses, whereas the RCSB Protein Data Bank (www.rcsb.org) was employed for retrieving the three-dimensional (3D) crystal structure of UDP-galactopyranose mutase from Mtb docked with UDP (UGM; PDB ID: 4RPJ), the 3D-crystal structure of arylamine- $N$-acetyltransferase from Mtb (TBNAT; PDB ID: 4BGF), and the 3D-structure of fucoxanthin (SDF ID file: A86). The docking results were verified by removing the ligand (UDP) from the PDB (PDB ID: 4RPJ) structure and re-docked back into the crystal structure of the enzyme with docking score $-6.2 \mathrm{kcal} / \mathrm{mol}$. The docking analyses were studied based on binding affinity values of the obtained enzyme-ligand complexes ( $\mathrm{kcal} / \mathrm{mol})$ along with hydrogen bonding, hydrophobic, and electrostatic interactions. The docking settings, preparation of PDBQT files for the enzymes and ligand, calculations, the protonation state, and the total charges were ascertained as previously detailed [58]. All docking results were graphically displayed using Discovery studio visualizer version v19.1.0.18287 (BIOVIA, San Diego, CA, USA) [59].

\section{Conclusions}

In this study, the role of fucoxanthin as an antitubercular molecule has been explored. Fucoxanthin unveiled effective anti-Mtb property with MIC values ranging from 2.8 to $4.1 \mu \mathrm{M}$ and SI (ranging from 6.1 to 8.9). We also determined the remarked anti-enzymatic properties of fucoxanthin against UGM and TBNAT as crucial drug targets implicated in Mtb cell wall biosynthesis. Anti-Mtb mechanism studies specified that the mechanism by which fucoxanthin-induced anti-Mtb activity could be related to its inhibitory action against UGM and TBNAT. Additionally, the safety index of fucoxanthin was determined. Molecular docking studies validated and rationalized the biological results obtained from in vitro assays. To sum up, fucoxanthin could be used as a candidate for the development of antimycobacterial agents, and hence could open new gates for overwhelming the problem of drug-resistant strains. Moreover, in-depth in vivo investigations and clinical trials should be further considered along with pharmacokinetic and pharmacodynamic studies. Integrated and comprehensive studies are also required to reveal the mechanism underlying the antitubercular activity of fucoxanthin. 
It is very important to highlight that our obtained results could lead to averting or diminishing the susceptibility to autoimmune diseases linked with Mtb infection in the genetically susceptible host.

Author Contributions: Conceptualization, M.Š., and S.T.S.H.; methodology, M.Š., and S.T.S.H.; software, S.T.S.H.; validation, M.Š., and S.T.S.H.; formal analysis, S.T.S.H.; investigation, M.Š., and S.T.S.H.; resources, M.Š., and S.T.S.H.; data curation, S.T.S.H.; writing—original draft preparation, M.Š., S.T.S.H., M.A.S., A.G., J.E., I.B.-N., and S.M.N.; writing—review and editing, M.Š., S.T.S.H., M.A.S., A.G., J.E., I.B-N., and S.M.N.; supervision, S.T.S.H.

Funding: This research received no external funding.

Acknowledgments: S.T.S.H. would like to thank Department of Applied Ecology, Faculty of Environmental Sciences, Czech University of Life Sciences, Prague, Czech Republic for technical support. All authors have read and approved the final version of the manuscript to be published.

Conflicts of Interest: The authors declare no conflict of interest.

\section{References}

1. Daletos, G.; Ancheeva, E.; Chaidir, C.; Kalscheuer, R.; Proksch, P. Antimycobacterial Metabolites from Marine Invertebrates. Arch. Pharm. 2016, 349, 763-773. [CrossRef] [PubMed]

2. Dong, M.; Pfeiffer, B.; Altmann, K.H. Recent developments in natural product-based drug discovery for tuberculosis. Drug Discov. Today 2017, 22, 585-591. [CrossRef] [PubMed]

3. Lee, H.; Suh, J.W. Anti-tuberculosis lead molecules from natural products targeting Mycobacterium tuberculosis ClpC1. J. Ind. Microbiol. Biotechnol. 2016, 43, 205-212. [CrossRef] [PubMed]

4. Soltero-Higgin, M.; Carlson, E.E.; Gruber, T.D.; Kiessling, L.L. A unique catalytic mechanism for UDP-galactopyranose mutase. Nat. Struct. Mol. Biol. 2004, 11, 539-543. [CrossRef]

5. Pan, F.; Jackson, M.; Ma, Y.F.; McNeil, M.J. Cell wall core galactofuran synthesis is essential for growth of mycobacteria. J. Bacteriol. 2001, 183, 3991-3998. [CrossRef]

6. Tefsen, B.; Ram, A.F.; van Die, I.; Routier, F.H. Galactofuranose in eukaryotes: Aspects of biosynthesis and functional impact. Glycobiology 2012, 22, 456-469. [CrossRef]

7. Pedersen, L.L.; Turco, S.J. Galactofuranose metabolism: A potential target for antimicrobial chemotherapy. Cell. Mol. Life Sci. 2003, 60, 259-266.

8. Westwood, I.M.; Bhakta, S.; Russell, A.J.; Fullam, E.; Anderton, M.C.; Kawamura, A.; Mulvaney, A.W.; Vickers, R.J.; Bhowruth, V.; Besra, G.S.; et al. Identification of arylamine $N$-acetyltransferase inhibitors as an approach towards novel anti-tuberculars. Protein Cell 2010, 1, 82-95. [CrossRef]

9. Butcher, N.J.; Tiang, J.; Minchin, R.F. Regulation of arylamine N-acetyltransferases. Curr. Drug Metab. 2008, 9, 498-504. [CrossRef]

10. Hassan, S.T.S.; Šudomová, M.; Berchová-Bímová, K.; Gowrishankar, S.; Rengasamy, K.R.R. Antimycobacterial, Enzyme Inhibition, and Molecular Interaction Studies of Psoromic Acid in Mycobacterium tuberculosis: Efficacy and Safety Investigations. J. Clin. Med. 2018, 7, 226. [CrossRef]

11. Hou, X.M.; Wang, C.Y.; Gerwick, W.H.; Shao, C.L. Marine natural products as potential anti-tubercular agents. Eur. J. Med. Chem. 2019, 165, 273-292. [CrossRef] [PubMed]

12. Zhang, H.; Tang, Y.; Zhang, Y.; Zhang, S.; Qu, J.; Wang, X.; Kong, R.; Han, C.; Liu, Z. Fucoxanthin: A Promising Medicinal and Nutritional Ingredient. Evid. Based Complement. Altern. Med. 2015, 2015, 72351. [CrossRef] [PubMed]

13. Peng, J.; Yuan, J.P.; Wu, C.F.; Wang, J.H. Fucoxanthin, a marine carotenoid present in brown seaweeds and diatoms: Metabolism and bioactivities relevant to human health. Mar. Drugs 2011, 9, 1806-1828. [CrossRef] [PubMed]

14. Yan, X.; Chuda, Y.; Suzuki, M.; Nagata, T. Fucoxanthin as the major antioxidant in Hijikia fusiformis, a common edible seaweed. Biosci. Biotechnol. Biochem. 1999, 63, 605-607. [CrossRef] [PubMed]

15. D’Orazio, N.; Gemello, E.; Gammone, M.A.; de Girolamo, M.; Ficoneri, C.; Riccioni, G. Fucoxantin: A treasure from the sea. Mar. Drugs 2012, 10, 604-616. [CrossRef] [PubMed]

16. Foo, S.C.; Yusoff, F.M.; Ismail, M.; Basri, M.; Yau, S.K.; Khong, N.M.H.; Chan, K.W.; Ebrahimi, M. Antioxidant capacities of fucoxanthin-producing algae as influenced by their carotenoid and phenolic contents. J. Biotechnol. 2017, 241, 175-183. [CrossRef] 
17. Garg, S.; Afzal, S.; Elwakeel, A.; Sharma, D.; Radhakrishnan, N.; Dhanjal, J.K.; Sundar, D.; Kaul, S.C.; Wadhwa, R. Marine Carotenoid Fucoxanthin Possesses Anti-Metastasis Activity: Molecular Evidence. Mar. Drugs 2019, 17, 338. [CrossRef]

18. Koo, S.Y.; Hwang, J.H.; Yang, S.H.; Um, J.I.; Hong, K.W.; Kang, K.; Pan, C.H.; Hwang, K.T.; Kim, S.M. Anti-obesity effect of standardized extract of microalga Phaeodactylum tricornutum containing fucoxanthin. Mar. Drugs 2019, 17, 311. [CrossRef]

19. Muradian, K.; Vaiserman, A.; Min, K.J.; Fraifeld, V.E. Fucoxanthin and lipid metabolism: A minireview. Nutr. Metab. Card. Dis. 2015, 25, 891-897. [CrossRef]

20. Gammone, M.A.; D'Orazio, N. Anti-obesity activity of the marine carotenoid fucoxanthin. Mar. Drugs 2015, 13, 2196-2214. [CrossRef]

21. D'Orazio, N.; Gammone, M.A.; Gemello, E.; De Girolamo, M.; Cusenza, S.; Riccioni, G. Marine bioactives. Pharmacological properties and potential applications against inflammatory diseases. Mar. Drugs 2012, 10, 812-833. [CrossRef] [PubMed]

22. Clinical and Laboratory Standards Institute. Susceptibility Testing of Mycobacteria, Nocardiae, and Other Aerobic Actinomycetes, 2nd ed.; Approved Standard M24-A2; CLSI: Wayne, PA, USA, 2011.

23. Liu, Z.; Sun, X.; Sun, X.; Wang, S.; Xu, Y. Fucoxanthin isolated from Undaria pinnatifida can interact with Escherichia coli and lactobacilli in the intestine and inhibit the growth of pathogenic bacteria. J. Ocean Univ. China 2019, 18, 926-932. [CrossRef]

24. Shannon, E.; Abu-Ghannam, N. Antibacterial derivatives of marine algae: An overview of pharmacological mechanisms and applications. Mar. Drugs 2016, 14, 81. [CrossRef] [PubMed]

25. Pérez, M.J.; Falqué, E.; Domínguez, H. Antimicrobial action of compounds from marine seaweed. Mar. Drugs 2016, 14, 52. [CrossRef]

26. Karpiński, T.M.; Adamczak, A. Fucoxanthin-An Antibacterial Carotenoid. Antioxidants 2019, 8, 239. [CrossRef]

27. Hassan, S.T.S.; Berchová-Bímová, K.; Petráš, J. Plumbagin, a Plant-Derived Compound, Exhibits Antifungal Combinatory Effect with Amphotericin B against Candida albicans Clinical Isolates and Anti-Hepatitis C Virus Activity. Phytother. Res. 2016, 30, 1487-1492. [CrossRef]

28. Feng, X.; Sureda, A.; Jafari, S.; Memariani, Z.; Tewari, D.; Annunziata, G.; Barrea, L.; Hassan, S.T.S.; Šmejkal, K.; Malaník, M.; et al. Berberine in Cardiovascular and Metabolic Diseases: From Mechanisms to Therapeutics. Theranostics 2019, 9, 1923-1951. [CrossRef]

29. Hou, L.L.; Gao, C.; Chen, L.; Hu, G.Q.; Xie, S.Q. Essential role of autophagy in fucoxanthin-induced cytotoxicity to human epithelial cervical cancer HeLa cells. Acta Pharm. Sin. 2013, 34, 1403-1410. [CrossRef]

30. Hosokawa, M.; Wanezaki, S.; Miyauchi, K.; Kurihara, H.; Kohno, H.; Kawabata, J.; Takahashi, K. Apoptosis-inducing effect of fucoxanthin on human leukemia cell HL-60. Food Sci. Technol. Res. 1999, 5, 243-246. [CrossRef]

31. Kim, K.N.; Heo, S.J.; Kang, S.M.; Ahn, G.; Jeon, Y.J. Fucoxanthin induces apoptosis in human leukemia HL-60 cells through a ROS-mediated Bcl-xL pathway. Toxicol. In Vitro 2010, 24, 1648-1654. [CrossRef]

32. Rokkaku, T.; Kimura, R.; Ishikawa, C.; Yasumoto, T.; Senba, M.; Kanaya, F.; Mori, N. Anticancer effects of marine carotenoids, fucoxanthin and its deacetylated product, fucoxanthinol, on osteosarcoma. Int. J. Oncol. 2013, 43, 1176-1186. [CrossRef] [PubMed]

33. Kim, S.K.; Pangestuti, R. Biological activities and potential health benefits of fucoxanthin derived from marine brown algae. Adv. Food Nutr. Res. 2011, 64, 111-128. [PubMed]

34. Chodisetti, S.B.; Rai, P.K.; Gowthaman, U.; Pahari, S.; Agrewala, J.N. Potential T cell epitopes of Mycobacterium tuberculosis that can instigate molecular mimicry against host: Implications in autoimmune pathogenesis. BMC Immunol. 2012, 13, 13. [CrossRef] [PubMed]

35. Ugarte-Gil, C.; Carrillo-Larco, R.M.; Kirwan, D.E. Latent tuberculosis infection and non-infectious co-morbidities: Diabetes mellitus type 2, chronic kidney disease and rheumatoid arthritis. Int. J. Infect. Dis. 2019, 80, 29-31. [CrossRef] [PubMed]

36. Tursi, S.A.; Lee, E.Y.; Medeiros, N.J.; Lee, M.H.; Nicastro, L.K.; Buttaro, B.; Gallucci, S.; Wilson, R.P.; Wong, G.C.L.; Tükel, Ç. Bacterial amyloid curli acts as a carrier for DNA to elicit an autoimmune response via TLR2 and TLR9. PLoS Pathog. 2017, 13, e1006315. [CrossRef]

37. Elkington, P.; Tebruegge, M.; Mansour, S. Tuberculosis: An Infection-Initiated Autoimmune Disease? Trends Immunol. 2016, 37, 815-818. [CrossRef] 
38. Shapira, Y.; Agmon-Levin, N.; Shoenfeld, Y. Mycobacterium tuberculosis, autoimmunity, and vitamin D. Clin. Rev. Allergy Immunol. 2010, 38, 169-177. [CrossRef]

39. Dubaniewicz, A. Mycobacterium tuberculosis heat shock proteins and autoimmunity in sarcoidosis. Autoimmun. Rev. 2010, 9, 419-424. [CrossRef]

40. Nicastro, L.; Tükel, Ç. Bacterial Amyloids: The Link between Bacterial Infections and Autoimmunity. Trends Microbiol. 2019, 27, 954-963. [CrossRef]

41. Borrelli, S.; Zandberg, W.F.; Mohan, S.; Ko, M.; Martinez-Gutierrez, F.; Partha, S.K.; Sanders, D.A.; Av-Gay, Y.; Pinto, B.M. Antimycobacterial activity of UDP-galactopyranose mutase inhibitors. Int. J. Antimicrob. Agents 2010, 36, 364-368. [CrossRef]

42. Villaume, S.A.; Fu, J.; N'Go, I.; Liang, H.; Lou, H.; Kremer, L.; Pan, W.; Vincent, S.P. Natural and Synthetic Flavonoids as Potent Mycobacterium tuberculosis UGM Inhibitors. Chemistry 2017, 23, 10423-10429. [CrossRef] [PubMed]

43. Turiján-Espinoza, E.; Salazar-González, R.A.; Uresti-Rivera, E.E.L.; Hernández-Hernández, G.E.; Ortega-Juárez, M.; Milán, R.; Portales-Pérez, D. A pilot study of the modulation of sirtuins on arylamine $N$-acetyltransferase 1 and 2 enzymatic activity. Acta Pharm. Sin. B 2018, 8, 188-199. [CrossRef] [PubMed]

44. Francis, S.; Laurieri, N.; Nwokocha, C.; Delgoda, R. Treatment of Rats with Apocynin Has Considerable Inhibitory Effects on Arylamine N-Acetyltransferase Activity in the Liver. Sci. Rep. 2016, 6, 26906. [CrossRef] [PubMed]

45. Madikane, V.E.; Bhakta, S.; Russell, A.J.; Campbell, W.E.; Claridge, T.D.; Elisha, B.G.; Davies, S.G.; Smith, P.; $\mathrm{Sim}, \mathrm{E}$. Inhibition of mycobacterial arylamine $N$-acetyltransferase contributes to anti-mycobacterial activity of Warburgia salutaris. Bioorg. Med. Chem. 2007, 15, 3579-3586. [CrossRef]

46. Kukongviriyapan, V.; Phromsopha, N.; Tassaneeyakul, W.; Kukongviriyapan, U.; Sripa, B.; Hahnvajanawong, V.; Bhudhisawasdi, V. Inhibitory effects of polyphenolic compounds on human arylamine $N$-acetyltransferase 1 and 2. Xenobiotica 2006, 36, 15-28. [CrossRef]

47. Van Straaten, K.E.; Kuttiyatveetil, J.R.; Sevrain, C.M.; Villaume, S.A.; Jiménez-Barbero, J.S.; Linclau, B.; Vincent, S.P.P.; Sanders, D.A. Structural basis of ligand binding to UDP-galactopyranose mutase from Mycobacterium tuberculosis using substrate and tetrafluorinated substrate analogues. J. Am. Chem. Soc. 2015, 137, 1230-1244. [CrossRef]

48. Abuhammad, A.; Lowe, E.D.; McDonough, M.A.; Shaw Stewart, P.D.; Kolek, S.A.; Sim, E.; Garman, E.F. Structure of arylamine $\mathrm{N}$-acetyltransferase from Mycobacterium tuberculosis determined by cross-seeding with the homologous protein from M. marinum: Triumph over adversity. Acta Cryst. D Biol. Cryst. 2013, 69, 1433-1446. [CrossRef]

49. Abuhammad, A.; Fullam, E.; Lowe, E.D.; Staunton, D.; Kawamura, A.; Westwood, I.M.; Bhakta, S.; Garner, A.C.; Wilson, D.L.; Seden, P.T. Piperidinols that show anti-tubercular activity as inhibitors of arylamine $N$-acetyltransferase: An essential enzyme for mycobacterial survival inside macrophages. PLoS ONE 2012, 7, e52790. [CrossRef]

50. Clinical and Laboratory Standards Institute. Laboratory Detection and Identification of Mycobacteria, 1st ed.; Approved Guideline; CLSI Document M48-A; Clinical and Laboratory Standards Institute: Wayne, PA, USA, 2008.

51. Semelková, L.; Janošcová, P.; Fernandes, C.; Bouz, G.; Jand’ourek, O.; Konečná, K.; Paterová, P.; Navrátilová, L.; Kuneš, J.; Doležal, M. Design, synthesis, antimycobacterial evaluation, and in silico studies of 3-(phenylcarbamoyl)-pyrazine-2-carboxylic acids. Molecules 2017, 22, 1491. [CrossRef]

52. Partha, S.K.; Sadeghi-Khomami, A.; Slowski, K.; Kotake, T.; Thomas, N.R.; Jakeman, D.L.; Sanders, D.A. Chemoenzymatic synthesis, inhibition studies, and x-ray crystallographic analysis of the phosphono analog of UDP-galp as an inhibitor and mechanistic probe for UDP-galactopyranose mutase. J. Mol. Biol. 2010, 403, 578-590. [CrossRef]

53. Bradford, M.M. A rapid and sensitive method for the quantitation of microgram quantities of protein utilizing the principle of protein-dye binding. Anal. Biochem. 1976, 72, 248-254. [CrossRef]

54. Zhang, Q.; Liu, H.W. Studies of UDP-galactopyranose mutase from Escherichia coli: An unusual role of reduced fad in its catalysis. J. Am. Chem. Soc. 2000, 122, 9065-9070. [CrossRef]

55. Veerapen, N.; Yuan, Y.; Sanders, D.A.; Pinto, B.M. Synthesis of novel ammonium and selenonium ions and their evaluation as inhibitors of udp-galactopyranose mutase. Carbohydr. Res. 2004, 339, 2205-2217. [CrossRef] [PubMed] 
56. Abuhammad, A.; Lack, N.; Schweichler, J.; Staunton, D.; Sim, R.B.; Sim, E. Improvement of the expression and purification of Mycobacterium tuberculosis arylamine $N$-acetyltransferase (TBNAT) a potential target for novel anti-tubercular agents. Protein Expr. Purif. 2011, 80, 246-252. [CrossRef]

57. Brooke, E.W.; Davies, S.G.; Mulvaney, A.W.; Pompeo, F.; Sim, E.; Vickers, R.J. An approach to identifying novel substrates of bacterial arylamine $N$-acetyltransferases. Bioorg. Med. chem. 2003, 11, 1227-1234. [CrossRef]

58. Hassan, S.T.S.; Švajdlenka, E. Biological evaluation and molecular docking of protocatechuic acid from Hibiscus sabdariffa L. As a potent urease inhibitor by an ESI-MS based method. Molecules 2017, 22, 1696. [CrossRef]

59. Biovia, D.S. Discovery Studio Modeling Environment; Dassault Systèmes: San Diego, CA, USA, 2016.

(C) 2019 by the authors. Licensee MDPI, Basel, Switzerland. This article is an open access article distributed under the terms and conditions of the Creative Commons Attribution (CC BY) license (http://creativecommons.org/licenses/by/4.0/). 